\title{
THE ROLE OF HUMAN MINOR HISTOCOMPATIBILITY ANTIGENS IN GRAFT FAILURE: A MINI-REVIEW
}

\author{
ELS GOULMY ${ }^{1}$, JOS POOL ${ }^{1}$, ELLEN VAN LOCHEM $^{1}$ and HENNIE VÖLKER-DIEBEN ${ }^{2}$ \\ Leiden, The Netherlands
}

This brief review will summarise our present knowledge on the possible role of human minor histocompatibility antigens (mHags) in graft failure. Following a short introduction on the possible nature of human mHags some in vitro studies dealing with graft failure and rejection will be discussed. To understand the possible impact of mHag disparity between organ donor and recipient on the outcome of organ and bone marrow (BM) grafting, information on their tissue expression is essential; hence a summary is given on the mHag tissue distribution studies performed so far. Finally, we will present our preliminary studies on the expression of mHag on human corneal tissue.

\section{POSSIBLE NATURE OF HUMAN mHag}

mHags are most probably naturally processed peptides of cytosolic proteins. ${ }^{1,2}$ The MHC restricted presentation of mHag peptides on the cell surface requires peptide import by an $A B C$ transporter dependent system into the endoplasmic reticulum, where they bind to newly sensitised MHC molecules. ${ }^{3}$ In the clinical setting of organ and BM transplantation between HLA matched, mHags mismatched individuals, the mHags are capable of inducing vigorous immune responses leading to graft rejection or graft-versus-host disease. ${ }^{4-6}$ The malespecific $\mathrm{H}-\mathrm{Y}$ is by far the simplest and also the most extensively studied mHag. The first report on $\mathrm{H}-\mathrm{Y}$ as a transplantation antigen is an untitled communication by Eichwald and Silmser in 1955. These authors observed that within two inbred strains of mice, most of the male-to-female skin grafts were rejected, whereas transplants made in other sex combinations

From: ${ }^{1}$ Department of Immunohaematology and Blood Bank, University Hospital, Leiden; ${ }^{2}$ Department of Ophthalmology, Diaconessenhuis, Leiden, The Netherlands.

Correspondence to: Els Goulmy, Department of Immunohaematology and Blood Bank, University Hospital, Rijnsburgerweg 10, NL-2333 AA Leiden, The Netherlands. Fax: 3171216751. nearly always succeeded. ${ }^{7}$ The term $\mathrm{H}-\mathrm{Y}$ antigen was introduced by Billingham and Silvers because the male-specific antigen can function as a classical transplantation antigen responsible for homograft rejection. ${ }^{8}$

\section{mHag AND GRAFT FAILURE: SOME RELATED CLINICAL STUDIES}

In the human situation the first report on involvement of $\mathrm{H}-\mathrm{Y}$ in transplantation appeared in $1976 .{ }^{9} \mathrm{It}$ concerned a clinical observation of rejection of a $\mathrm{BM}$ graft from a male sibling by his HLA-identical sister. In vitro analysis of the post-transplant peripheral blood lymphocytes (PBLs) of this female patient (HLA phenotype: HLA-A2, -A2, -B44, -B60, -Cw3, -Cw5, -DR4, -Drw6) showed unambiguously strong cytotoxic $\mathrm{T}$ cell (CTL) responses specific for male HLA-A2 positive target cells. ${ }^{9}, 10$ Whether the H-Y specific CTLs actually mediated the allograft rejection, we do not know. It must be remarked, however, that most probably the female patient, who suffered from severe aplastic anaemia, had been sensitised to the $\mathrm{H}-\mathrm{Y}$ antigen prior to $\mathrm{BM}$ transplantation through multiple, mainly male, blood transfusions and pregnancies. This assumption is based on our subsequent observations. As shown in Table I, PBLs derived from four additional cases showed, after in vitro restimulation with HLA-identical male cells, exactly the same phenomenon, namely HLA restricted (-A1, -A2 and/or -B7) anti-H-Y CTL activity. In one patient (i.e. case 5, Table I), the H-Y specific HLA-B7 restricted cytotoxicity was detected shortly after an acutely rejected kidney donated by an HLA-identical male sibling (unpublished observation). In circumstances similar to ours, other investigators also described the presence of HLA restricted $\mathrm{H}-\mathrm{Y}$ directed cytotoxicity. ${ }^{11,12}$

Although in our first case we could not formally prove that the $\mathrm{H}-\mathrm{Y}$ specific CTLs actually mediated the rejection of the male BM allograft, some years 
Table I. MHC restricted cytotoxic T cell (CTL) responses against the mHag H-Y

\begin{tabular}{lll}
\hline Patient/disease $^{\mathrm{a}}$ & CTLs & CTL specificity \\
\hline 1. AA & Post BM grafting & HLA-A2 H-Y \\
2. AA & Multitransfused & HLA-A2 H-Y \\
3. AA & Multitransfused & HLA-A2 H-Y/HLA-B7 H-Y \\
4. AA & Multitransfused & HLA-A1 H-Y \\
5. Kidney failure & Post renal transplant & HLA-B7 H-Y \\
\hline
\end{tabular}

AA, aplastic anaemia; BM, bone marrow.

${ }^{\text {a }}$ All patients were female.

ago we were confronted with a case with a fatal outcome in which anti-H-Y CTLs were most probably mainly responsible for BM graft failure. It concerned a multitransfused female patient suffering from myelodysplasia after treatment for Hodgkin's disease. In vitro analysis prior to $\mathrm{BM}$ transplantation demonstrated the presence of HLA-A1 restricted anti-H-Y CTLs (Table I, case 4). Since the father appeared to be the only HLA compatible related donor, he was the obvious choice (despite the presence of the patient's pretransplant anti-H-Y CTLs). Notwithstanding intensive pretransplant immunosuppressive treatment and the donation of $\mathrm{T}$ cell depleted marrow, there was no recovery of the bone marrow haematopoietic function. ${ }^{13}$ In view of the latter case, expression of mHag on haematopoietic stem cells (HPC) might be relevant in presensitised patients receiving a mHag-positive $\mathrm{T}$ cell depleted marrow graft. For that purpose, the expression of the male specific antigen $\mathrm{H}-\mathrm{Y}$ was studied for its expression on HPC. It became clear that indeed $\mathrm{H}-\mathrm{Y}$ is expressed on CFU-GEMM, CFUGM and BFU-E $:^{14}$ Experiments carried out to study the expression of other (non-sex-linked) mHag (designated HA-1 to HA-5), demonstrated expression of all the latter antigens on HPC. ${ }^{14,15}$

The clinical relevance of the H-Y alloantigen in the context of HLA-A2 to the results of human kidney allograft transplantation has also been determined. A retrospective study showed that HLA-A2 females receiving HLA-A2 male kidneys survived for a significantly shorter time than did non-HLA-A2 male kidneys in non-HLA-A2 female recipients. ${ }^{16}$

\section{mHag TISSUE DISTRIBUTION STUDIES}

Naturally the impact of mHags on the outcome of organ and BM grafting is dependent on, amongst other things, their tissue distribution. Table II summarises the tissues and cells studied to date. We observed ubiquitous versus restricted tissue distribution of the mHags analysed. ${ }^{17}$ Expression of the nonsex-linked mHags, i.e. HA-1, -2 and $-5,{ }^{17}$ is restricted to the haematopoietic cell lineage including epidermal-derived Langerhans cells, ${ }^{18}$ whereas H-Y, HA-3 and HA-4 were found to be expressed on cells of all tissues tested (see Table II).

The contribution of mHags to the cascade of inflammatory events, especially in cutaneous allograft rejection, is largely dependent on which type of antigen presenting cell (APC) the antigen is presented on. Namely, $\mathrm{T}$ cells can be inactivated instead of activated when occupation of their $\mathrm{T}$ cell receptor (TCR) by antigen is not accompanied by appropriate co-stimulatory signal(s).$^{19}$ This socalled state of $\mathrm{T}$ cell anergy is marked by unresponsiveness to subsequent adequate triggering by professional APC and can be induced in several ways. ${ }^{19}$ Keratinocytes, fibroblasts, and many other

Table II. Tissue distribution of human minor histocompatibility antigens

\begin{tabular}{|c|c|c|c|c|c|c|}
\hline & HA-1 & HA-2 & HA-3 & H-Y & HA-4 & HA-5 \\
\hline $\begin{array}{l}\text { Haematopoietic stem cells } \\
\text { Thymocytes } \\
\text { Peripheral blood lymphoctyes } \\
\text { PBL blasts } \\
\text { EBV BLCL } \\
\text { Monocytes } \\
\text { Dendritic cells }\end{array}$ & $\begin{array}{l}\text { HA-1 } \\
\text { HA-1 } \\
\text { HA-1 } \\
\text { HA-1 } \\
\text { HA-1 } \\
\text { HA-1 } \\
\text { HA-1 }\end{array}$ & $\begin{array}{l}\text { HA-2 } \\
\text { HA-2 } \\
\text { HA-2 } \\
\text { HA-2 } \\
\text { HA-2 } \\
\text { HA-2 } \\
\text { HA-2 }\end{array}$ & $\begin{array}{c}\text { HA-3 } \\
\text { n.t. } \\
\text { HA-3 } \\
\text { HA-3 } \\
\text { HA-3 } \\
\text { HA-3 } \\
\text { HA-3 }\end{array}$ & $\begin{array}{l}\text { H-Y } \\
\text { H-Y } \\
\text { H-Y } \\
\text { H-Y } \\
\text { H-Y } \\
\text { H-Y } \\
\text { H-Y }\end{array}$ & $\begin{array}{c}\text { HA-4 } \\
\text { n.t. } \\
\text { HA-4 } \\
\text { HA-4 } \\
\text { HA-4 } \\
\text { HA-4 } \\
\text { HA-4 }\end{array}$ & $\begin{array}{c}\text { HA-5 } \\
\text { n.t. } \\
\text { HA-5 } \\
\text { HA-5 } \\
\text { HA-5 } \\
\text { HA-5 } \\
\text { HA-5 }\end{array}$ \\
\hline $\begin{array}{l}\text { Leukaemic cells } \\
\text { Myeloid } \\
\text { Lymphocytic }\end{array}$ & $\begin{array}{l}\text { HA-1 } \\
\text { HA-1 }\end{array}$ & $\begin{array}{l}\text { HA-2 } \\
\text { HA-2 }\end{array}$ & $\begin{array}{l}\text { HA-3 } \\
\text { HA-3 }\end{array}$ & $\begin{array}{l}\mathrm{H}-\mathrm{Y} \\
\mathrm{H}-\mathrm{Y}\end{array}$ & $\begin{array}{l}\text { HA-4 } \\
\text { HA-4 }\end{array}$ & $\begin{array}{l}\text { HA-5 } \\
\text { HA-5 }\end{array}$ \\
\hline $\begin{array}{l}\text { Langerhans cells (skin) } \\
\text { Fibroblasts } \\
\text { Keratinocytes } \\
\text { Melanocytes } \\
\text { Melanomas }\end{array}$ & HA-1 & HA-2 & $\begin{array}{l}\text { HA-3 } \\
\text { HA-3 } \\
\text { HA-3 } \\
\text { HA-3 } \\
\text { HA-3 }\end{array}$ & $\begin{array}{l}\text { H-Y } \\
\text { H-Y } \\
\text { H-Y } \\
\text { H-Y } \\
\text { H-Y }\end{array}$ & $\begin{array}{l}\text { HA-4 } \\
\text { n.t. } \\
\text { HA-4 } \\
\text { HA-4 }\end{array}$ & n.t. \\
\hline $\begin{array}{l}\text { Cord endothelial cells } \\
\text { Kidney proximal tubular epithelium cells }\end{array}$ & & & $\begin{array}{l}\text { HA-3 } \\
\text { HA-3 }\end{array}$ & $\begin{array}{l}\mathrm{H}-\mathrm{Y} \\
\mathrm{H}-\mathrm{Y}\end{array}$ & & \\
\hline
\end{tabular}

PBL, peripheral blood lymphocytes; EBV BLCL, Epstein-Barr virus B lymphoblastoid cell line; n.t., not tested. 
Table III. mHag expression on human corneal tissue: preliminary results

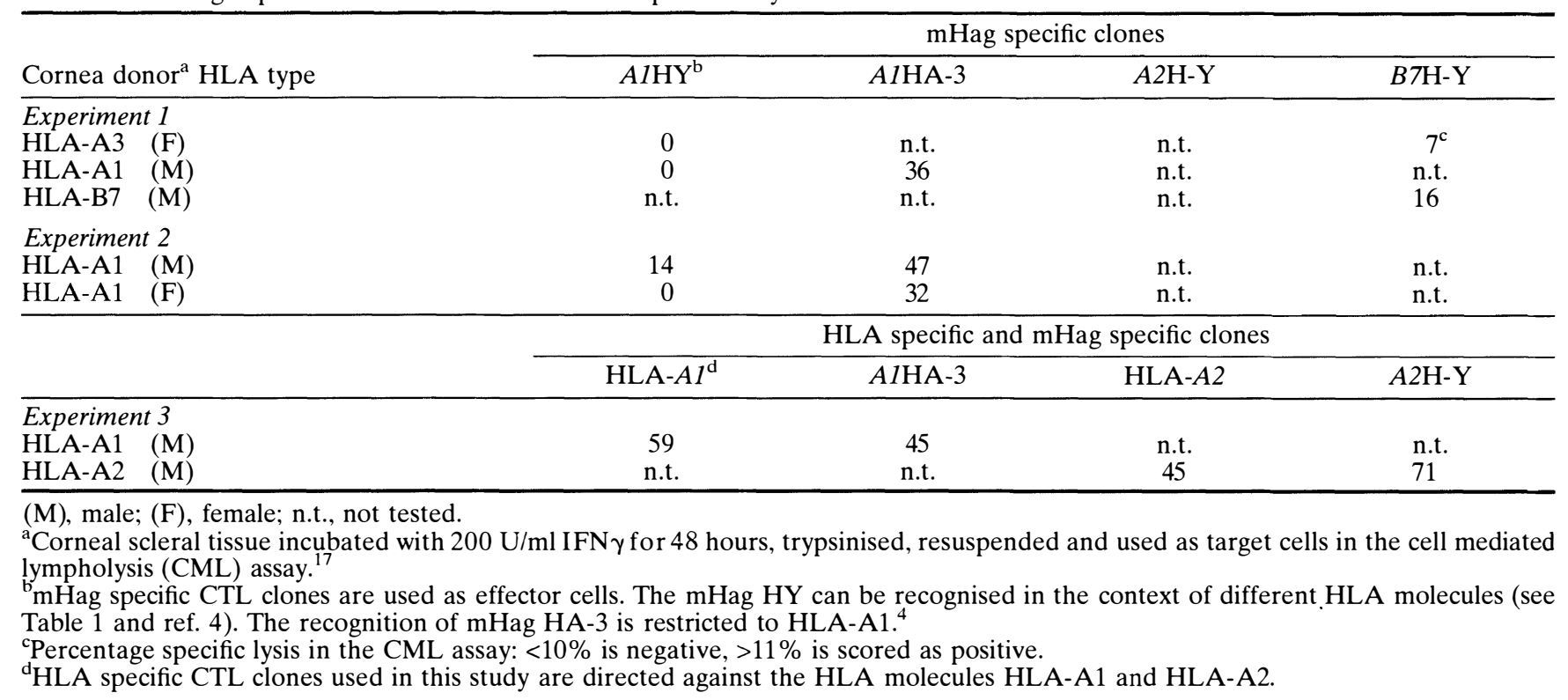

so-called non-classical $\mathrm{APC}^{20}$ have been found to have no or little capacity of $T$ cell activation, even after interferon-gamma induced HLA class II expression. ${ }^{21,22}$ HLA class II expressing keratinocytes (also found in a GVHD-affected skin, ${ }^{20}$ were even found to tolerise hapten-specific $\mathrm{T}$ cell clones in vitro. ${ }^{23}$

The expression of mHag on non-classical APCs, such as HA-3 on keratinocytes, could play a role in the induction of $\mathrm{BM}$ transplantation tolerance. We earlier investigated the development of acquired tolerance for mHag HA-3 in a healthy chimaeric BM recipient 7 years after HLA-identical but HA-3 mismatched $\mathrm{BMT}^{24}$ We found persistent host specific HA-3 expression on patient's skin tissue after $\mathrm{BM}$ transplantation together with disappearance of anti-host HA-3 CTLs which paralleled the in vivo state of tolerance. We hypothesised, therefore, that direct presentation of host mHags by parenchymal host tissues functioning as non-classical or inadequate APC could result in tolerisation of anti-host CTLs induced following BM engraftment. ${ }^{24}$ According to this hypothesis, the induction of longterm graft-host tolerance versus graft-host reactivity after BM transplantation across mHags barriers would depend on the tissue distribution of the mHags in question.

Similarly, the need for adequate signals for $\mathrm{T}$ cell activation and subsequent murine corneal allograft rejection was earlier put forward by Chandler et al. ${ }^{25}$ Indeed, inadequate presentation of the $\mathrm{mHag} \mathrm{H}-\mathrm{Y}$ in a murine cornea model led to a specific state of unresponsiveness to $\mathrm{H}-\mathrm{Y}^{26}{ }^{26}$ On the other hand when the corneal graft, which is normally devoid of Langerhans cells (LC), became infiltrated with donor-derived LC through graft pretreatment with latex beads, rejection of mHag-disparate corneal grafts was observed. ${ }^{27}$ Although, as discussed above, keratinocytes are not capable of inducing primary $\mathrm{T}$ cell activation, they do have limited capacity to activate memory $\mathrm{T}$ cells. ${ }^{28}$ In this context it is of importance to note that allogeneic corneas that were transplanted into eyes of presensitised mice were uniformly subjected to an acute rejection process. ${ }^{29}$ With regard to the role of mHag in the latter study, it was shown that the highest rate of rejection occurred among grafts that confronted their hosts with multiple mHag, with or without major histocompatibility antigens. $^{29}$

\section{MHAg EXPRESSION ON HUMAN CORNEAL TISSUE: PRELIMINARY RESULTS}

It is well known that corneal tissue recipients do benefit from an HLA matched graft, ${ }^{30}$ especially the high-risk patients. ${ }^{31}$ Even in those HLA matched cases, corneal graft survival, after excluding the nonimmunological causes for graft failure, is well below $100 \%{ }^{32}$ Since HLA antigens are expressed on corneal tissue, ${ }^{33}$ it would, in view of their characteristics, not be surprising that mHags will coexist as well. To elaborate on the latter assumption, we recently started to analyse the functional expression of human mHags on corneal scleral tissue. Our welldefined CTL clones specific major HLA antigens HLA-A1 and HLA-A2 and for the mHag H-Y (see Table. I) and for the non-sex-linked mHag HA- $3^{4}$ were used as effector cells in cell mediated lympholysis (CML) assays. As target cells, trypsinised corneal scleral tissues were used. Table III demonstates the results of our first small series of experiments. Both HLA antigens and mHag H-Y and HA-3 are readily detectable on corneal tissue; they function as target molecules for CTL clones. These observations are in agreement with our earlier 
studies on the broad mHag tissue expression of $\mathrm{H}-\mathrm{Y}$ and HA-3. Likewise, it is to be expected (Table II), but has yet to be proven, that all mHag we can test for to date are expressed on LCs residing in the corneal epithelium. This knowledge is especially important in view of the LC's characteristic as an adequate APC.

We demonstrate here for the first time, to our knowledge, the functional expression of mHags on human corneal tissue. Naturally these limited data need confirmation and extension. The present studies may bring us closer to understanding the impact of mHag mismatching between corneal graft donor and recipient in the human situation. The role of mHag disparities, in especially presensitised recipients, was recently clearly demonstrated in a murine study. ${ }^{29}$ Encouraged by the latter data we feel it is justified to continue our search for mHags on corneal tissue and their possible role in the outcome of corneal grafting.

The contributions of Marleen de Bueger, Paul Voogt and Erik Marijt are greatly appreciated. We thank Ingrid Curiël for typing the manuscript. This work was supported in part by the J. A. Cohen Institute for Radiopathology and Radiation Protection (IRS), the Dutch Cancer Society and the Dutch Cornea Foundation.

Key words: Cornea, Human, Minor histocompatibility antigens.

\section{REFERENCES}

1. Wallny HJ, Rammensee HG. Identification of classical minor histocompatibility antigen as cell-derived peptide. Nature 1990;343:275-8.

2. Falk K, Rötzschke O, Rammensee HG. Cellular peptide composition governed by major histocompatibility complex class I molecules. Nature 1990;348: 248-51.

3. Momburg F, Ortiz-Navarrete V, Neefjes J, et al. Proteasome subunits encoded by the major histocompatibility complex are not essential for antigen presentation. Nature 1992;360:174-7.

4. Goulmy E. Minor histocompatibility antigens in man and their role in transplantation. Transplant Rev 1988;2:29-53.

5. Martin PJ. Increased disparity for minor histocompatibility antigens as a potential cause of increased GvHD risk in marrow transplantations from unrelated donors compared with related donors. Bone Marrow Transplant 1991;8:217-23.

6. Beatty PG, Hervé P. Immunogenetic factors relevant to acute GvHD. In: Burakoff SJ, Deeg DHJ, Ferrara S, Atkinson K, editors. Graft-versus-host disease: immunology, pathophysiology and treatment. New York: Dekker, 1989: 415-23.

7. Eichwald EJ, Slimser CR. Transplant Bull 1955;2: 148-9.

8. Billingham RE, Silvers WK. Studies on tolerance of the Y chromosome antigen in mice. J Immunol 1960; 85:14-26.

9. Goulmy E, Termijtelen A, Bradley BA, Van Rood JJ. Alloimmunity to human H-Y. Lancet 1976;2:1206.

10. Goulmy E, Termijtelen A, Bradley BA, Van Rood JJ. Y-antigen killing by $\mathrm{T}$ cells of women is restricted by HLA. Nature 1977;266:544-5.

11. Singal DP, Wadia YJ, Naipaul N. In vitro cell-mediated cytotoxicity to the male specific $\mathrm{H}-\mathrm{Y}$ antigen in man. Hum Immunol 1981;2:45-53.

12. Pfeffer PF, Thorsby E. HLA restricted cytotoxicity against male specific (H-Y) antigen after acute rejection of an HLA identical sibling kidney: clonal distribution of the cytotoxic cells. Transplantation 1982;33:52-6.

13. Voogt PJ, Fibbe WE, Marijt WA, et al. Rejection of bone-marrow graft by recipient derived cytotoxic $T$ lymphocytes against minor histocompatibility antigens. Lancet 1990;335:131-4.

14. Voogt PJ, Goulmy E, Fibbe WE, et al. Minor histocompatibility antigen $\mathrm{H}-\mathrm{Y}$ is expressed in human hematopoietic progenitor cells. J Clin Invest 1988; 82:906-12.

15. Marijt WAF, Veenhof WFJ, Goulmy E, et al. Minor histocompatibility antigens $\mathrm{T}$ cell clones inhibit human hematopoietic progenitor cell growth by a mechanism that is dependent on direct cell-cell contact. Blood 1993;82:3378-85.

16. Goulmy E, Bradley BA, Lansbergen Q, Van Rood JJ. The importance of H-Y incompatibility in human organ transplantation. Transplantation 1978;25:315-9.

17. De Bueger M, Bakker A, Van Rood JJ, Van der Woude F, Goulmy E. Tissue distribution of human minor histocompatibility antigens: ubiquitous versus restricted tissue distribution indicates heterogeneity among human cytotoxic $\mathrm{T}$ lymphocyte-defined nonMHC antigens. J Immunol 1992;149:1788-94.

18. Van Lochem EG, Van de Keur M, Mommaas M, et al. Expression of cytotoxic $\mathrm{T}$ cell defined minor histocompatibility antigens on human peripheral blood dendritic cells and skin derived Langerhans cells. Manuscript submitted for publication.

19. Schwartz RH. A cell culture model for $\mathrm{T}$ cell clonal anergy. Science 1990;24:1349-56.

20. Mueller DL, Jenkins MK, Schwartz RH. Clonal expansion versus functional clonal inactivation: a costimulatory signalling pathway determines the outcome of a $\mathrm{T}$ cell receptor occupancy. Annu Rev Immunol 1989;7:445-80.

21. Breathnach SM, Shimada S, Kovac Z, Katz SI. Immunologic aspects of acute cutaneous GVHD: decreased density and antigen presenting function of $\mathrm{Ia}+\mathrm{LC}$ and absent antigen presenting function of Ia+ keratinocytes. J Invest Dermatol 1986;86:226-34.

22. Geppert TD, Lipsky PE. Dissection of defective antigen-presentation by interferon gamma treated fibroblasts. J Immunol 1987;138:385-92.

23. Gaspari AA, Jenkins MK, Katz SI. Class II MHC bearing keratinocytes induce antigen-specific unresponsiveness in hapten specific TH1 clones. J Immunol 1988;141:2216-20.

24. De Bueger M, Bakker A, Goulmy E. Acquired tolerance for minor histocompatibility antigens after HLA identical bone marrow transplantation. Int Immunol 1992;4:53-7.

25. Chandler JW, Ray-Keil L, Gillette TE. Experimental corneal allograft rejection: description of murine model and new hypothesis of immunopathogenesis. Curr Eye Res 1982;2:387-98.

26. Peeler JS, Callanan DG, Luckenbach MW, Niederkorn JY. Presentation of the H-Y antigen on Langerhans cell negative corneal grafts down regulates the cytotoxic $\mathrm{T}$ cell response and converts responder strain mice into phenotypic nonresponders. J Exp Med 1988;168: 1749-66.

27. Ross J, He Yu-Guang, Pidherney M, Mellon J, Niederkorn JY. The differential effects of donor versus 
host Langerhans cells in the rejection of MHC-matched corneal allografts. Transplantation 1991;52:857-61.

28. De Bueger M, Bakker A, Goulmy E. Human keratinocytes activate primed major and minor antigen specific Th cells in vitro. Transplant Immunol 1993;1:52-9.

29. Sonoda Y, Streilein JW. Orthotopic corneal transplantation in mice: evidence that the immunogenetic rules in rejection do not apply. Transplantation 1992; 54:694-704.

30. Batchelor JR, Casey TA, Gibbs DC, et al. HLA matching and corneal grafting. Lancet 1976;1:551-4.
31. D'Amaro J, Völker-Dieben HJ, Kruit PJ, et al. Influence of pretransplant sensitisation on the survival of corneal allografts. Transplant Proc 1991;23:368-72.

32. Völker-Dieben HJM, D'Amaro J. Corneal transplantation: a single center experience 1976-1988. In: Terasaki PJ, editor. Clinical transplants. Los Angeles: UCLA Tissue Typing Laboratories, 1988:249-61.

33. Newson DA, Takasugi M, Kenyon RR. Human corneal grafts in vitro: morphology and histocompatibility (HLA) antigens of pure cell populations. Invest Ophthalmol 1974;13:23-32. 